\title{
THE ROLE OF EMPLOYEE MOTIVATION ON THE RELATIONSHIP BETWEEN HRM PRACTICES AND SERVICE QUALITY IN HEALTHCARE ORGANIZATION
}

\author{
Totok Sasongko *)
}

\begin{abstract}
The human resources management in the healthcare institution is essential to enable the delivery of efficient and effective medical services. This study conducted to investigate how HRM practices can enhance service quality and proposes an integrated framework in which perceived HRM practices are related to employee commitment, which in turn related to perceived service quality performance. Five HRM practices was selected. A questionnaire was constructed. The quantitative methodology was applied to collect and analyze data. Data was collected from 270 employees (including nurse and doctor) and bottom manager in Dr. Radjiman Wediodiningrat in Indonesia. The result shows that the selected HRM practices all significantly and meaningfully can predicted the employee motivation, in which feedback and recogniton was the most effective practices. The result also shows that employee motivation is an effective predictor of service quality performance. Lastly, employee motivation has a role as mediator effect toward the relationship between HRM practice and service quality. This research suggests that HRM departement need to chooses human resources management practices properly that can increase employe motivation and their service quality performances.
\end{abstract}

Keywords: HRM Practices, Motivation, Service Quality, Healthcare Organization

\section{INTRODUCTION}

\subsection{Research Background}

Human Resources Management (HRM) plays a vital role in the success of the health sector. It is essential to enable the delivery of efficient and effective medical services, to achieve patient satisfaction (McHugh, Johnston, \& McClelland, 2007; Elarabi \& Johari, 2014). Empirical studies show that there is a relationship between HRM practices and aspects of service delivery to patients (Clark, 1999; Weech-Maldonado, Dreachslin, Dansky, De Souza, \& Gatto, 2002). Therefore, it can suggest that to service sector, especially healthcare industry, the HRM Practices are related to service quality.

Scholars have repeatedly called for better understanding of the relationship between HRM and aspects of service quality. Those study has found that HRM practices are directly related to service quality performance (Schneider \& Bowen, 1993; Peccei \& Rosenthal, 2001; Humphrey, Ehrich, Kelly, Sandall, Redfern, Morgan, \& Guest, 2003), and others found that these relationships are mediated by employee behaviors, intention, and attitudes (Delaney \& Huselid, 1996), such as trust (Tzafrir \& Gur, 2007), commitment (Dzansi \& Dzansi, 2010), satisfaction (Ott \& van Dijk, 2005), and this study motivation. One of the biggest challenges for organizations, in particular for HR function is creating and maintaining a motivated employee workforce to increasing their performance at work.

Although the existing literature assert the importance of HRM practice to develop motivation, and further to develop high performance in productivity and quality level of customer services (Amstrong 2008), empirical research which focuses on the incorporating HRM activites especially in healthcare institutions in order to improve employee motivation is rare. There is no agreement on which practice qualifies as an aspect of HRM (Boselie, Dietz, \& Boon, 2005). It is reasonable then to investigate and explore which one best of HRM practices in contibutes to increase employee motivation which in turn further influences their intention to provide best service to the patiens. 


\subsection{Research Problem}

Based on the above reasoning, researcher need to investigate whether certain HRM practices contribute to employee motivation and then to service quality performance.

\subsection{Research Purpose}

The first objective of this study is to advance the understanding of the link between perception of HRM practices and perceived service quality by examining mediating role of employee motivation. This study motivated by the fact that despite the importance of HRM practices to improving service quality performance, few study have investigated the mediating role of employee motivation to the relationship between HRM practices and services quality, especially in Indonesian context. The second objective is to answer question which HRM activities are most effective for increasing employee motivation. Examining these activities in the healthcare sector in Indonesia (in Psychiatry Hospital Dr. Radjiman Wediodiningrat) is importance because it is under pressure to operate more efficiently and effectively. The way they implement their HRM practices may be as important determinant of employee attitudes (Edgar \& Geare, 2005). The third objective is to examine does the increasing employee motivation will increase service quality performance. The results will enable managers to decide HRM activities in their HRM plans and how to deliver them most effectively.

\section{THEORETICAL FRAMEWORK AND HYPHOTESES DEVELOPMENT}

\subsection{Theoretical Framework}

\subsubsection{Human Resources Management Practices in Healthcare Organization}

Human resources management is defined as a strategic and coherent approach to the management of an organization most valued asset - the people working there (Amstrong, 2008). Human resources are the key for keeping the organization in the market so competitive. These human resources need to be managed effectively to achieve the required performance of the organization (Cania, 2014). As a concept of managing people, HRM has many practices and activities should handles by departement of human resources. Researchers have over the years proposed varied lists of HRM practices, and there is no agreement on which practice qualifies as an aspect of HRM (Boselie, Dietz, \& Boon, 2005). Guest (1997) suggests seven practices, namely, selection, training, appraisal, rewards, job design, involvement and status and security. Dessler (2016), suggest many activity practices in HR department, such as, analysis and design at work, recruitment and selection, training and development, performance management, compensation and benefits, employee relations, personnel policies, compliance with laws and support for the strategy. In their studies, Tabiu \& Nura (2013) using six practices, namely, recruitment/selection, training/development, employee involvement, reward/remuneration, maintenance, and separation. In healthcare organization, management might seek to implement progressive HRM practices that encourage service oriented behavior and show concern for employees' organizational and personal needs. Tzafrir \& Gur (2007) suggest five dimensional practices of HRM in health care organization, namely: leadership and supervision; training; compensation; promotion and career development; and feedback and recognition. Ott \& van Dijk (2005) recommend seven HRM activities for fulfill job satisfaction and client satisfaction, in hospital area: A personal development plan, Additional job-related training during the past two years, Job performance review during the past two years past two years, Regular departmental meetings (at least monthly), A protocol in case of a labor-shortage. Predictable work schedules, and A leadership style of the manager which is transparent and supportive. Agarwal, Garg, \& Pareek (2011) suggest several competencies needed for HRM in health services, including: rational recruitment procedures to meet the organizational goals, timeliness of the reward systems, transparent transfer policy, and effective support systems. All of that study study concluded that the management of human resources is of crucial importance in enabling the delivery of efficient and effective services. This study was choosing the HRM practices proposed by Tzafrir \& Gur (2007). 
Besides these practices are consistent with the universalistic view (e.g. Pfeffer, 1994), it is also valuable to enhancing employee motivation (Tzafrir, 2006).

\subsubsection{Human Resources Management Practices in Healthcare Organization HRM Practices and Employee Motivation}

One of the biggest challenges for organizations, in particular for HR function is creating and maintaining a motivated employee workforce to increasing their performance at work. Motivation is the inner drive that pushes individuals to act or perform. Many scholars agree that motivation is the psychological process that causes the arousal, direction, intensity and persistence of behavior (Locke \& Latham, 2004; Pinder, 1998). As a process that arouses, energizes, directs, and sustains behavior and performance (Luthans, 1998), motivation proposes varying set of factors influencing of it (Harder, 2008). It is including a set of internal and external forces that initiate work-related behavior, and then determine its form, direction, intensity and duration (Pinder, 1998), and directed behavior (Nelson \& Quick, 2003), then determine the level of employee job performance.

Dessler (2016) proposes theory that human resource management will contribute to basic measures of an organization's performance, such as quality, profitability, and customer satisfaction. Decisions of HRM practice such as whom to hire, what to pay, what training to offer, and how to evaluate employee performance directly affect employees' motivation and ability to provide goods and services that customers value. Also Amstorng's (2008) proposes the theory that HRM Practice will develop employee motivation, commitment and job engagement. Thus, the first hypothesis is as follows:

$\mathrm{H}_{1} \quad$ A selected HRM Practices (leadership, supervision, training, compensation, promotion, career development, feedback and recognition) will be related to employee motivation.

\subsubsection{Employee Motivation and Service Quality}

In healthcare organization, employees as the most valued assets (Amstrong, 2008), having level of service performance. This performance, fundamentally depend on many behavioral factors like employee motivation, satisfaction, commitment, trust and others, but the area of this study is focused only on employee motivation as this factor highly influence the performance of employees. This factor was chosen for two reasons. First, the strong and well-motivated medical profession is critical to the success of the healthcare reform, in the delivery of services to patients (McHugh, Johnston, \& McClelland, 2007), and second, it is one of the best policies of managers to increase effectual job management amongst employees in organizations. Getting highly motivated employees to do their best work even in strenuous circumstances, is one of the great challenges for services organization, including in the healthcare sector. Thus, the second hypothesis is as follows:

$\mathrm{H}_{2} \quad$ Employee motivation is positively related to perceived service quality.

\subsubsection{Alternative Model}

As an addition, this research proposes that the relationship between HRM practices and service quality is partially mediated by employee motivation, which suggests a direct link between HRM practices and service quality. Thus, the third hypothesis are:

$\mathrm{H}_{3}$ The relationship between HRM practices and service quality is partially mediated by employee motivation

\section{RESEARCH METHOD}

\subsection{Research Design}

This research can be classify as quantitave research with (survey) questionnaire as the research tools. A survey questionnaire comprising of demographic information and measures of the perception of HRM Practices, motivation and services quality was used to elicit data from the present study. The data were analyzed using the Statistical Package for Social Sciences (SPSS) 
program. The descriptive statistics of respondents' demographic profiles were tabulated. For testing the hypothesis, multiple regression analysis was carried out. Steps for mediation of Barron and Kenny (1986) were employed, to test the hypothesized of mediating role of employee motivation. First, the independent variable (HRM Practices) must be related to the mediator (employee motivation). Second, the mediator must be related to the dependent variable (service quality). Third, the independent variable must be related to the dependent variable. Fourth, the independent variable must have no effect on the dependent variable for full mediation, or should become significantly smaller for partial mediation.

\subsection{Population and Sample}

The research concentrated on the Psychiatry Hospital Dr. Radjiman Wediodiningrat, Indonesia. There were nine sub department, which employ about 836 employees and managers to provide services to patients. In order to adjust the proper respondent, sample selected were those who has been working for at least a year, and those who on the bottom level that serve patients directly (bottom manager, supervisor and nurse). To collect data, a random sampling technique was employed. It was a sampling method in which all members of a population group have an equal and independent chance of being selected. The researcher gives a letter of permission to the general manager of each sub department and ask for help to distribute a questionnaire to each service employee who work in sub department. The researcher was attached a cover letter to each survey that stressing the aspects of confidentiality and anonymity. Every week in a month, the researcher, distributed reminders to general manager by telephone calls in order to improve the response rate. By the end of the process, from 500 questionnaires, 270 questionnaires (more than 50\%) is processed to the next analysis.

\subsection{Research Variables}

Perception of HRM Practices. The perceptions of human resource management practices were measured based on five dimension Tzafrir \& Gur (2007) of HRM practices. Items then collected from the extant literature and finally 15 items were generated. Leadership and supervision, which encompass three items based on Ott \& van Dijk (2005) related the way managers threat staff (e.g., "A leadership style of the manager which is transparent and supportive"). Training which incorporates three items based on Ott \& van Dijk (2005) related to the training that received by staff (e.g., "Organization provides additional job-related training"). Compensation, which integrate one item from Tzafrir \& Gur (2007) related paid compensation system (i.e., "System by which organization has paid, motivate people to work especially hard") and two items from Agarwal, Garg, \& Pareek (2011) related support system effectiveness of labour-shortage (e.g., The organization provides a protocol in case of a labour-shortage). Promotion and career development which include one item from Agarwal, Garg, \& Pareek (2011) (i.e., "The organization provide timeliness of the reward systems") and two items based on Ott \& van Dijk (2005) related (e.g. "The organization provide performance review") related to organizational preference to have reward system and performance review; and feedback and recognition, which integrate three items based on Tzafrir \& Gur (2007) related to feedback and recognition from the organization and managers about the attention staff give to customer (e.g. "My manager recognise the attention $\mathrm{i}$ give to customer"). Items were answered on a 5-point Likert scale, with the score ranges from strongly disagree (1) to strongly agree (5).

Employee motivation. Mawoli \& Babandako (2011) motivation determinant scale was adopted in this work. It was consisted of six items: "My achievement on the current job is satisfactory"; "I am given due recognition at work"; "The work itself is interesting and challenging"; "I am given due responsibilities at work to execute"; "My advancement (i.e. promotion) on the current job is satisfactory"; and "Personal growth (i.e. skills acquired through training and development) on the current job is satisfactory." Respondent was requested to indicate their level agreement of the items on five-point agree-disagree scale. 
Perceived Service Quality. A 22 Item of SERVQUAL instrument for assessing perceived service quality was used in this study, but excludes any consideration of expectations. As suggested by by Cronin \& Taylor (1994), the excludes is based on the premise that it is difficult to conceptualize expectations, so that expectations can be disregarded in service quality assessment. Bowen (1990) suggests that measuring employee perception is an acceptable way for dealing with Healthcare organizations that provide high contact, customized personal services. In the healthcare industries, the interaction between patients and healthcare service providers (employees) is an integral part of the service quality process (Conway \& Willcocks 1997; Benbassat \& Taragin 1998). Employees, view as putting a strong emphasis on meeting customer needs and delivering excellence in service (Pugh, Dietz, Wiley, \& Brooks, 2002). By existence, finding that there is a positive correlation between employees' and customers' perceptions of service quality (Schneider \& Bowen 1993; Johnson 1996), it is acceptable for measuring employee perception. Items were answered on a five-point Likert scale, with the score ranges from strongly disagree (1) to strongly agree (5).

\subsection{Research Framework}

Based on the explanation described above, it can be described the research model in the chart as follows:

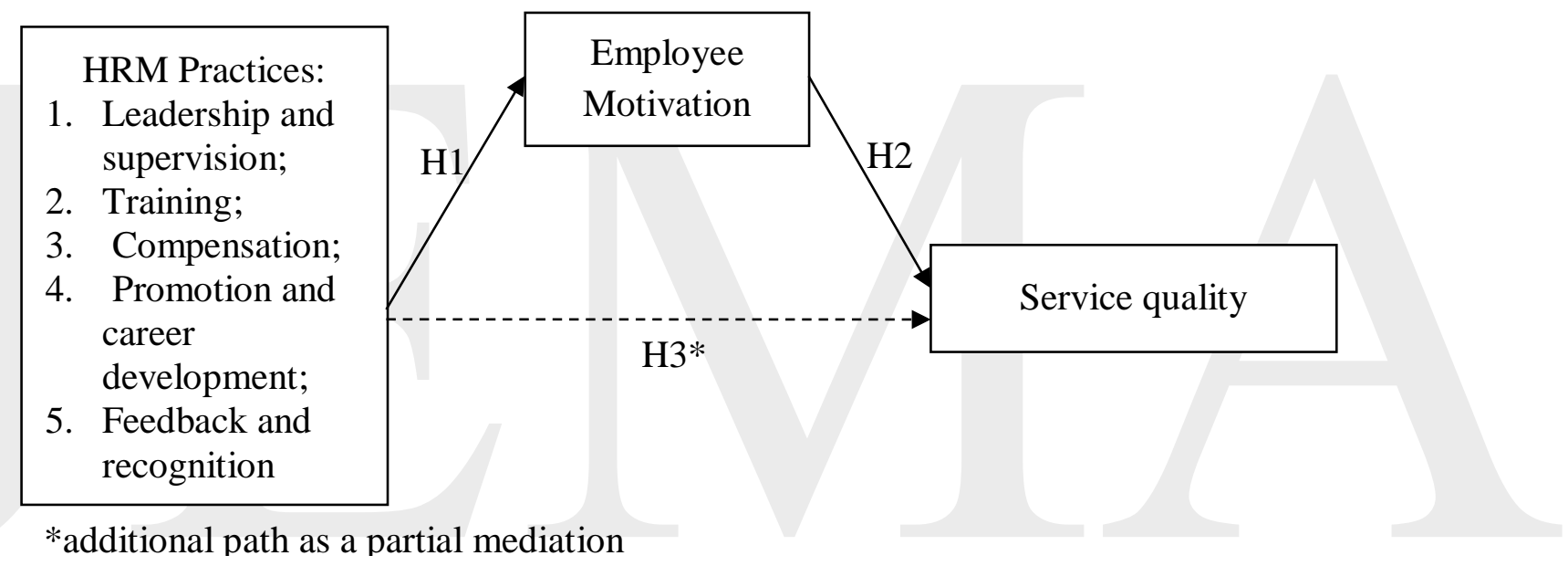

Picture 1 Research Framework

\section{RESEARCH RESULT AND ANALYSIS}

\subsection{Descriptive Analysis}

There are three respondent characteristics in this study; gender, age, and education levels. The sample size is made up of a majority of females $(n=155,57.4 \%)$ over males $(n=115,42.6 \%)$. The main age level range is 31 to 40 years old $(n=69,25.6 \%)$, and the majority of respondents have a bachelor's degree $(n=167,61.9 \%)$.

\subsection{Validity and Reliability}

Table 1 contains the results of factor analysis of 15 HRM practice items. The exploratory factor analysis was based on eigenvalue exceed 1 and factor loading exceed 0.5 , With the test value of Kaiser-Meyer-Olkin (KMO) 0.935 and $p<0.001$, it suggests the use of factor analysis. In the end, 15 items of HRM practices were identified that had a factor loading exceed 0.5, and the five factors of HRM practices (Leadership \& Supervision, Training, Compensation, Promotion \& career development, Feedback \& recognition) with eigenvalues bigger than 1 were extracted. The variance explained for HRM practices was $63.138 \%$. 
Jurnal IImiah Bidang Akuntansi dan Manajemen (JEMA) Vol. 15 No. 1 (2018)

http://riset.unisma.ac.id/index.php/jema

Table 1. Result of Exploratory factor analysis of HRM practices

\begin{tabular}{|c|c|c|c|c|c|}
\hline Variables & $\begin{array}{l}\text { Leadership \& } \\
\text { Supervision }\end{array}$ & Training & Compensation & $\begin{array}{l}\text { Promotion \& Career } \\
\text { Development }\end{array}$ & $\begin{array}{l}\text { Feedback \& } \\
\text { Recognition }\end{array}$ \\
\hline LS1 & 0.726 & & & & \\
\hline LS2 & 0.767 & & & & \\
\hline LS3 & 0.723 & & & & \\
\hline $\mathrm{T} 1$ & & 0.831 & & & \\
\hline $\mathrm{T} 2$ & & 0.792 & & & \\
\hline $\mathrm{T} 3$ & & 0.821 & & & \\
\hline $\mathrm{C} 1$ & & & 0.798 & & \\
\hline $\mathrm{C} 2$ & & & 0.753 & & \\
\hline C3 & & & 0.764 & & \\
\hline PC1 & & & & 0.803 & \\
\hline $\mathrm{PC} 2$ & & & & 0.821 & \\
\hline PC3 & & & & 0.722 & \\
\hline FR1 & & & & & 0.700 \\
\hline FR2 & & & & & 0.752 \\
\hline FR3 & & & & & 0.744 \\
\hline Eigenvalue & 2.235 & 4.038 & 3.053 & 2.543 & 3.855 \\
\hline $\begin{array}{l}\text { Variance } \\
\text { explained (\%) }\end{array}$ & 8.979 & 19.896 & 10.655 & 8.733 & 15.875 \\
\hline
\end{tabular}

Note: Cummulative variance explained $63.138 \%$

Table 2 shows the means, standard deviations and reliability analysis, and also correlation among variables. The reliability of the measures was assessed using the inter-item consistency measure of Cronbach's alpha. The alpha scale for all the independent variables and dependent variable ranged from 0.784 to 0.922 and extended the minimum acceptable value of 0.7 (Nunnally 1978). This reliable test is confirmed if the all items accepted.

Table 2. Means, standard deviations, reliability, and correlations

\begin{tabular}{|l|c|c|c|c|c|c|c|c|c|c|}
\hline & $\mathrm{M}$ & $\mathrm{SD}$ & $\alpha$ & 1 & 2 & 3 & 4 & 5 & 6 & 7 \\
\hline Leadership & 3.024 & 0.737 & 0.843 & 1 & & & & & & \\
\hline Training & 3.170 & 0.707 & 0.794 & $0.591^{* *}$ & 1 & & & & & \\
\hline Compensation & 3.209 & 0.722 & 0.814 & $0.561^{* *}$ & $0.501^{* *}$ & 1 & & & & \\
\hline Promotion & 3.215 & 0.724 & 0.811 & $0.549^{* *}$ & $0.542^{* *}$ & $0.650^{* *}$ & 1 & & & \\
\hline Feedback & 3.550 & 0.662 & 0.832 & $0.348^{* *}$ & $0.395^{* *}$ & $0.353^{* *}$ & $0.425^{* *}$ & 1 & & \\
\hline Motivation & 3.368 & 0.651 & 0.784 & $0.455^{* *}$ & $0.419^{* *}$ & $0.411^{* *}$ & $0.466^{* *}$ & $0.558^{* *}$ & 1 & \\
\hline SQ & 3.208 & 0.387 & 0.922 & $0.478^{* *}$ & $0.414^{* *}$ & $0.520^{* *}$ & $0.546^{* *}$ & $0.324^{* *}$ & $0.538^{* *}$ & 1 \\
\hline
\end{tabular}

$* * p \leq 0.01$ (two tailed)

\subsection{Research Analysis}

This regression test was conducted to test the hypothesis, by running three steps of analysis separately. First, analysis included all of hypothesized antecedent. Second, analysis included the hypothesized consequence. Third, verified the mediate relationship of 'employee motivation' between 'HRM practices' and 'service quality'. Table 3 summarizes this research findings. 
Jurnal IImiah Bidang Akuntansi dan Manajemen (JEMA) Vol. 15 No. 1 (2018)

http://riset.unisma.ac.id/index.php/jema

Table 3. Multiple Regression Analysis

\begin{tabular}{|c|c|c|c|c|c|c|c|c|}
\hline & \multicolumn{4}{|c|}{ motivation } & \multicolumn{4}{|c|}{ Service quality } \\
\hline & B & $\mathrm{t}$ & $\operatorname{sig}$ & & B & $\mathrm{t}$ & Sig & \\
\hline \multicolumn{9}{|l|}{ Step 1 (H1) } \\
\hline Leadership & $0.053 * *$ & 2.782 & 0.006 & & $0.029 *$ & 2.523 & 0.012 & \\
\hline Training & $0.037 * *$ & 2.891 & 0.003 & & $0.027 *$ & 2.613 & 0.025 & \\
\hline compensation & $0.037 * *$ & 2.876 & 0.003 & & $0.037 * *$ & 3.035 & 0.003 & \\
\hline Promotion & $0.039^{*}$ & 1.988 & 0.050 & & $0.048 * * *$ & 3.857 & 0.000 & \\
\hline Feeback & $0.131 * * *$ & 7.416 & 0.000 & & $0.022 * * *$ & 2.112 & 0.027 & \\
\hline $\mathrm{F}$ & & & & $36.893 * * *$ & & & & $31.354 * * *$ \\
\hline $\mathrm{R}^{2}$ & & & & 0.411 & & & & 0.373 \\
\hline \multicolumn{9}{|l|}{ Step 2 (H2) } \\
\hline Motivation & & & & & $0.319 * * *$ & 10.447 & 0.000 & \\
\hline $\mathrm{F}$ & & & & & & & & $109.146 * * *$ \\
\hline $\mathrm{R}^{2}$ & & & & & & & & 0.289 \\
\hline \multicolumn{9}{|l|}{ Step 3 (H3) } \\
\hline Leadership & & & & & 0.019 & 1.679 & 0.094 & \\
\hline Training & & $\square$ & & & 0.004 & 0.339 & 0.735 & \\
\hline compensation & & & & & $0.034 * *$ & 2.899 & 0.004 & \\
\hline Promotion & & & & & $0.041 * *$ & 3.391 & 0.001 & \\
\hline Feeback & & & & & 0.014 & 1.264 & 0.207 & \\
\hline Motivation & & & & & 0.200 & 5.619 & 0.000 & \\
\hline $\mathrm{F}$ & & & & & & & & $34.415 * * *$ \\
\hline $\mathrm{R}^{2}$ & & 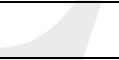 & & & & & & 0.440 \\
\hline
\end{tabular}

$* p \leq 0.05, * * p \leq 0.01, * * * p \leq 0.001$

Each hypothesis was tested by examining coefficient significance. Referring to table 3 , the result shows all steps were in significant result. Step one confirm that all five measures of HRM practice: 'leadership \& supervision' $(\mathrm{B}=0.053, p \leq 0.01)$, 'training' $(\mathrm{B}=0.037, p \leq 0.01)$, 'compensation' $(\mathrm{B}=0.037, p \leq 0.01)$, 'promotion \& career development' $(\mathrm{B}=0.039, p \leq 0.05)$, 'feedback \& recognition' ( $\mathrm{B}=0.131, p \leq 0.001)$, significantly and positively influenced 'employee motivation', thus supporting first hypothesis (HI). This finding, then give full empirical support to the relationship between 'HRM practices' and 'employee motivation'. Step two confirm the second hypothesis $(H 2)$ that 'employee motivation' significantly and positively influence 'service quality' $(\mathrm{B}=0.319, p \leq 0.001)$. Thus, the second hypothesis $(H 2)$ was also supported. To prove the third hypothesis $(H 3)$ mediating role of employee motivation, condition for mediation of Barron and Kenny (1986) was employed. First, the independent variable (HRM Practices) must be related to the mediator (employee motivation). Second, the mediator must be related to the dependent variable (service quality). Third, the independent variable must be associated with the dependent variable. Fourth, the independent variable must have no consequence on the dependent variable for full mediation, or should become significantly smaller for partial mediation. The first and second conditions, both were already supported by $H 1$ and $H 2$. For the third condition, as seen in step 1 on table 3, the results showed that HRM practices ('leadership \& supervision' ( $\mathrm{B}=0.029, p \leq 0.01$ ), 'training' $(\mathrm{B}=0.027, p \leq 0.05)$, 'compensation' $(\mathrm{B}=0.037, p \leq 0.01)$, 'promotion \& career development' ( $\mathrm{B}=0.048, p \leq 0.001)$, 'feedback \& recognition' $(\mathrm{B}=0.022, p \leq 0.001))$ positively 
and significantly influence 'service quality'. To analyze the final condition, when 'employee motivation' was added to the equation, as seen in step 3 on the table 3 , the results showed that 'leadership \& supervision' $(\mathrm{B}=0.019, p>0.05)$, 'training' $(\mathrm{B}=0.027, p>0.05)$, and 'feedback \& recognition' $(\mathrm{B}=0.022, p>0.05)$, were no longer significant, while compensation $(\mathrm{B}=0.034, p \leq$ $0.01)$, and promotion \& career development $(\mathrm{B}=0.041, p \leq 0.01)$ were still significant but its strength become smaller, thus the relationship between 'HRM practices' and 'service quality' was mediated by 'employee motivation'. 'Compensation', and 'promotion \& career development' influence 'service quality' directly and indirectly through 'employee motivation' (partial mediation), though 'leadership \& supervision', 'training', and 'feedback \& recognition' only indirectly through 'employee motivation' (full mediation).

\section{RESEARCH CONCLUSION AND LIMITATION}

\subsection{Conclusion}

This research focused on examining the mediation effect of employee motivation on the relationship between employees' perceptions of HRM practices and perceived Service quality. Coherent with our prediction, the result of the study demonstrated that employee motivation mediated the relationship between perception of HRM practices and perceived service quality. This finding then has made several implications to enrich the body of knowledge.

First, This study found that all selected HRM practices (leadership \& supervision, training, compensation, promotion \& career development, feedback \& recognition) had a substantial influence on employee motivation, where feedback \& recognition were the most significant factors influencing employee motivation, followed by training, compensation, leadership \& supervision. The weakest effect was promotion \& career development. These empirical results indicated that the higher the employees' perception of HRM efforts, the higher employee motivation will be. It is also suggested the importance role of various HRM practices in building employee motivation. Empirical results showed that different HRM practices have different impact on employee motivation. Second, this study also found that the positive perception of HRM practices were more potential to increase employee motivation, where in turn influence employee's perception of service quality performance. The way management performs will contribute to increase or decrease their employee motivation, that will lead on employing service quality performance. Third, this study could enrich the body of knowledge regarding antecedent and consequence of employee motivation in health care organization by providing empirical support for the mediating function of employee motivation in the relationship between HRM practices and service quality. It was built an integrated framework on the relationship between HRM practices, employee motivation and service quality. This work also contributes implication for human resource managers of healthcare organizations. It is very significant to identify HRM practices that foster employee motivation. As we found that employee motivation play prominent role as predictor of service quality performance, it is important to select HRM practice that increases employee motivation.

\subsection{Limitation}

Nevertheless, this research has some limitation. First, motivation is invisible and internal construct (Pinder, 1998). It's difficult actually to see and measure it directly. This study expect that work motivation manifest itself in attitude (i.e satisfaction) as in equity theory, whereas for other theories (e.g. goal-setting) motivation manifest in behavior (e.g. Enhanced performance when ability is constant). Therefore, It can suggest for further research trying to measure motivation in behavioral point of persuasion (e.g. experimental research). Second, the respondents in the survey are limited to the psychiatric healthcare organization. Total healthcare in Indonesia is 2.460 (http://sirs.buk.depkes.go.id/), the sample might be excessively small and too specific to be representative of the total healthcare, although the sample reasonably represents the characteristics of the population. However, we recommended for future surveys, to consider increasing the number of respondents from other healthcare to increase their representation. 
Jurnal IImiah Bidang Akuntansi dan Manajemen (JEMA) Vol. 15 No. 1 (2018)

http://riset.unisma.ac.id/index.php/jema

\section{REFERENCES}

Agarwal, A., Garg, S., \& Pareek, U. (2011). Strengthening Human Resource Practices in Healthcare in India: The Road Ahead. Journal, Indian Academy of Clinical Medicine, 12(1), 39.

Benbassat, J., \& Taragin, M. (1998). What is adequate healthcare and how can quality of care be improved?. International Journal of Healthcare Quality Assurance, 11(2), 58-64.

Boselie, P., Dietz, G., \& Boon, C. (2005). Commonalities and Contradictions in Research on Human Resource Management and Performance" Human Resource Management Journal, $13,3,67-94$.

Bowen, J. (1990). Development of a taxonomy of services to gain strategic marketing insights. Journal of the Academy of Marketing Science, 18(1), 43-49.

Cania, L. (2014). The Impact of Strategic Human Resource Management on Organizational Performance. Economia. Seria Management, 17(2), 373-383.

Clark, L. (1999). Multi-skilling for success. Facilities, 17(7/8), 272-279.

Conway, T., \& Willcocks, S. (1997). The role of expectations in the perception of healthcare quality: developing a conceptual model. International Journal of Healthcare Quality Assurance, 10(3), 131-140.

Cronin Jr, J. J., \& Taylor, S. A. (1994). SERVPERF versus SERVQUAL: reconciling performancebased and perceptions-minus-expectations measurement of service quality. The Journal of Marketing, 125-131.

Delaney, J. T., \& Huselid, M. A. (1996). The impact of human resource management practices on perceptions of organizational performance. Academy of Management journal, 39(4), 949969.

Dessler, G. (2016). Fundamentals of human resource management. Boston, Massachusetts: Pearson.

Dzansi, D. Y., \& Dzansi, L. W. (2010). Understanding the impact of human resource management practices on municipal service delivery in South Africa: An organizational justice approach.African Journal of Business Management, 4(6), 995-1005.

Edgar, F., \& Geare, A. (2005). HRM practice and employee attitudes: different measures-different results. Personnel review, 34(5), 534-549.

Elarabi, H. M., \& Johari, F. (2014). The Impact of Human Resources Management on Healthcare Quality. Asian Journal of Management Sciences \& Education, 3(1), 13-22.

Guest, D. E. (1997). Human resource management and performance: a review and research agenda.International journal of human resource management,8(3), 263-276.

Harder, M. (2008). How do rewards and management styles influence the motivation to share knowledge?. Centre for Strategic Management and globalization (SMG) Working Paper No. 6.

Humphrey, C., Ehrich, K., Kelly, B., Sandall, J., Redfern, S., Morgan, M., \& Guest, D. (2003). Human resources policies and continuity of care. Journal of health organization and management, 17(2), 102-121. 
Johnson, J. W. (1996). Linking employee perceptions of service climate to customer satisfaction.Personnel psychology, 49(4), 831-851.

Locke, E. A., \& Latham, G. P. (2004). What should we do about motivation theory? Six recommendations for the twenty-first century.Academy of Management Review, 29(3), 388403.

Luthans, F. (1998). Organizational Performance (8th ed.). Boston: Irwin McGraw-Hill

Mawoli, M. A., \& Babandako, A. Y. (2011). An evaluation of staff motivation, dissatisfaction and job performance in an academic setting. Australian Journal of Business and Management Research,1(9), 1-13.

McHugh, M., Johnston, K., \& McClelland, D. (2007). HRM and the management of clinicians within the NHS. International Journal of Public Sector Management, 20(4), 314-324.

Nelson, D. L., \& Quick, J.C. (2003). Organizational Behaviour: Foundation, Realities and Challenges (4th ed.), Australia: Thomson South-Western

Nunnally, J. C. (1978). Psychometric Theory, 2nd ed. New York: McGraw-Hill.

Ott, M., \& van Dijk, H. (2005). Effects of HRM on client satisfaction in nursing and care for the elderly.Employee Relations, 27(4), 413-424.

Peccei, R., \& Rosenthal, P. (2001). Delivering customer-oriented behaviour through empowerment: An empirical test of HRM assumptions. Journal of Management Studies, 38(6), 831-857.

Pfeffer, J. (1994). Competitive advantage through people: Unleashing the power of the work force. Boston: Harvard Business School Press.

Pinder, C. C. (1998). Work Motivation in Organizational Behaviour. Upper Saddle River, New Jersey: Prentice-Hall.

Pugh, S. D., Dietz, J., Wiley, J. W., \& Brooks, S. M. (2002). Driving service effectiveness through employee-customer linkages. The Academy of Management Executive, 16(4), 73-84.

Schneider, B., \& Bowen, D. E. (1993). The service organization: Human resources management is crucial. Organizational Dynamics, 21(4), 39-52.

Tabiu, A., \& Nura, A. A. (2013). Assessing The Effects of Human Resource Management (HRM) Practices on Employee Job Performance: A Study of Usmanu Danfodiyo University Sokoto. Journal of Business Studies Quarterly, 5(2).

Tzafrir, S. S. (2006). A universalistic perspective for explaining the relationship between HRM practices and firm performance at different points in time. Journal of Managerial Psychology, 21(2), 109-130.

Tzafrir, S. S., \& Gur, A. B. (2007). HRM practices and perceived service quality: The role of trust as a mediator. Research and Practice in Human Resource Management, 15(2), 1-20.

Weech-Maldonado, R., Dreachslin, J. L., Dansky, K. H., De Souza, G., \& Gatto, M. (2002). Racial/ethnic diversity management and cultural competency: the case of Pennsylvania hospitals. Journal of Healthcare Management, 47, 111-126. 
Jurnal IImiah Bidang Akuntansi dan Manajemen (JEMA) Vol. 15 No. 1 (2018)

http://riset.unisma.ac.id/index.php/jema

*) Totok Sasongko, Department of Management, University of Tribhuwana Tunggadewi, Malang, Indonesia (E-Mail: totok95sasongko@yahoo.co.id) 